\title{
Flood Impacts Across Scales: towards an integrated multi-scale approach for Malaysia
}

\author{
Victoria Bell ${ }^{1, a}$, Balqis Rehan ${ }^{2}$, Bakti Hasan-Basri ${ }^{4}$, Helen Houghton-Carr ${ }^{1}$, James Miller ${ }^{1}$, Nick Reynard ${ }^{1}$, Paul Sayers ${ }^{5}$, \\ Elizabeth Stewart ${ }^{1}$, Mohd Ekhwan Toriman², Badronnisa Yusuf ${ }^{2}$, Zed Zulkafli², Sam Carr ${ }^{5}$, Rhian Chapman ${ }^{1}$, Helen Davies ${ }^{1}$, \\ Eva Fatdillah ${ }^{2}$, Matt Horritt ${ }^{5}$, Shabir Kabirzad ${ }^{2}$, Alexandra Kaelin ${ }^{1}$, Tochukwu Okeke ${ }^{2}$, Ponnambalam Rameshwaran ${ }^{1}$ and \\ Mike Simpson 6
}

\author{
${ }^{1}$ UKCEH, Maclean Building, Crowmarsh Gifford, Wallingford, Oxfordshire, OX10 8BB, United Kingdom \\ ${ }^{2}$ UPM, Universiti Putra Malaysia Civil engineering Department, Faculty of Engineering, Serdang, 43400 Seri Kembangan, Selangor, Malaysia \\ ${ }^{3}$ UKM, Center for Research in Development, Social \& Environment, FSSK Universiti Kebangsaan Malaysia, Selangor, Malaysia \\ ${ }^{4}$ UUM, Universiti Utara Malaysia Department of Economics and Agribusiness, School of Economics, Finance, and Banking, Sintok, 06010, \\ Kedah, Malaysia \\ ${ }^{5}$ Sayers and Partners, High Street Watlington, OX49 5PY, United Kingdom \\ ${ }^{6}$ HR Wallingford, Howbery Park, Wallingford, Oxfordshire, OX10 8BA, United Kingdom
}

\begin{abstract}
Flooding is a recurring challenge across Malaysia, causing loss of life, extensive disruption and having a major impact on the economy. A new collaboration between Malaysia and UK, supported by the Newton-Ungku Omar Fund, aims to address a critical and neglected aspect of large-scale flood risk assessment: the representation of damage models, including exposure, vulnerability and inundation. In this paper we review flood risk and impact across Malaysia and present an approach to integrate multiple sources of information on the drivers of flood risk (hazard, exposure and vulnerability) at a range of scales (from household to national), with reference to past flood events. Recent infrastructure projects in Malaysia, such as Kuala Lumpur's SMART Tunnel, aim to mitigate the effects of flooding both in the present and, ideally, for the foreseeable future. Our collaborative project aims to develop and assess a new multi-scale model of flood risk in Malaysia for current and projected future scenarios, and to address climate adaptation questions of policy relevance for flood stakeholders. This approach will enable us to identify the preferred adaptation pathways given multiple scenarios of climate and socio-economic change in Malaysia, and, beyond the life of our project, internationally.
\end{abstract}

\section{Introduction}

Catastrophic flooding poses an ongoing and increasing risk to communities worldwide (Munich Re., 2017). Flooding presents a recurring challenge across Malaysia, with major historical events including the widespread floods in Kuala Lumpur in 1971 which claimed 61 lives, and floods in Johor in 2006 causing \$1 billion in damage (Shaari et al., 2016). The severity of the flood risk in Malaysia was demonstrated most recently in 2014 when 21 people lost their lives in an event that caused extensive displacement and disruption. The economic damage was estimated in excess of $\$ 500 \mathrm{~m}$ (Reuters, 2015), with significant disruption for the production of rubber and palm oil (USDA, 2015). Addressing flood risk in Malaysia has become a national priority and a recognised prerequisite for sustainable development in this region.
Motivation is high, as organisational and personal memories of the 2014 floods are still evident (Ghazali, 2019).

Flood risk is typically defined and analysed in terms of three main factors: hazard, exposure and vulnerability (Crichton, 1999). The hazard is the probability and extent of a damaging event (in this case a flood). Exposure to a given flood consists of what can be damaged by it, for example, buildings, people, critical infrastructure and land. Finally, vulnerability refers to the susceptibility of the buildings, people, or land to flooding. Quantification of vulnerability can include the capacity of a population to cope with a flood (including preparedness and post-event recovery). The UN office for Disaster Risk Reduction report of Flood Hazard and Risk assessment (UNISDR, 2017) noted that 'Vulnerability represents a crucial step in properly evaluating flood impact and all quantitative 
indicators that are the final product of probabilistic risk assessment. So far, in flood risk assessment, this is probably the weakest link.'

Historically, flood risk management has often developed through an iterative process in which flood events act as the catalyst for change (Sayers et al., 2015). This process has delivered important incremental changes, but is unlikely to enable the transformational change required to manage future risks in an effective and efficient way. Nonetheless flood events, such as those recently experienced in both Malaysia and in the UK, provide a window of opportunity to make more strategic decisions regarding investment in flood management infrastructure and land use planning choices. An international consortium led by Malaysian and UK researchers funded by the Newton-Ungku Omar Fund is currently developing a new multi-scale approach ('Flood Impact Across Scales', or 'FIAS') to flood risk for both present day and projected future scenarios, and to address climate adaptation questions of policy relevance for flood stakeholders. The development of an improved, 'next-generation' approach to flood impact assessment is timely for the contribution that can be made to developing revised flood risk strategies in Malaysia and internationally.

Here we review present-day flood risk and impact across Malaysia and outline an approach to integrate multiple sources of information on the drivers of flood risk (hazard, exposure and vulnerability) at a range of scales from household to national, with reference to past flood events.

\section{Flood risk in Malaysia}

\subsection{Flood hazard}

Flooding, in particular monsoon flooding, is an everpresent threat in Malaysia. Located within the equatorial zone, Malaysia's weather is influenced by the alternating north-east and south-west monsoons. The north-east monsoon occurs from mid-November to March and causes heavy rain particularly on the east coast of Peninsular Malaysia. The west coast is protected from the south-west monsoon by Sumatra Island, and the highest intensity rainfall experienced by the west coast occurs during the inter-monsoon periods. Figure 1 shows the dominant weather patterns affecting Malaysia, including the monsoon seasons.

During the inter-monsoon period severe flash flooding can occur, with devastating impacts in densely populated areas such as the Klang Valley, in the south-west of Peninsular Malaysia (highlighted in Figure 4).

Malaysia has been subject to numerous major flood events over the last 100 years. The most recent flood of 2014 devastated northern and eastern regions of Peninsular Malaysia and was thought to have a 1000-year return period (Mohamed et al., 2017). The flooding was caused by record breaking rainfall of $1295 \mathrm{~mm}$ in the northern state of Kelantan, exceeding the mean annual rainfall of $900 \mathrm{~mm}$, and which led to Kelantan river levels exceeding the danger level by 5 to $7 \mathrm{~m}$ (Baharuddin et al., 2015).

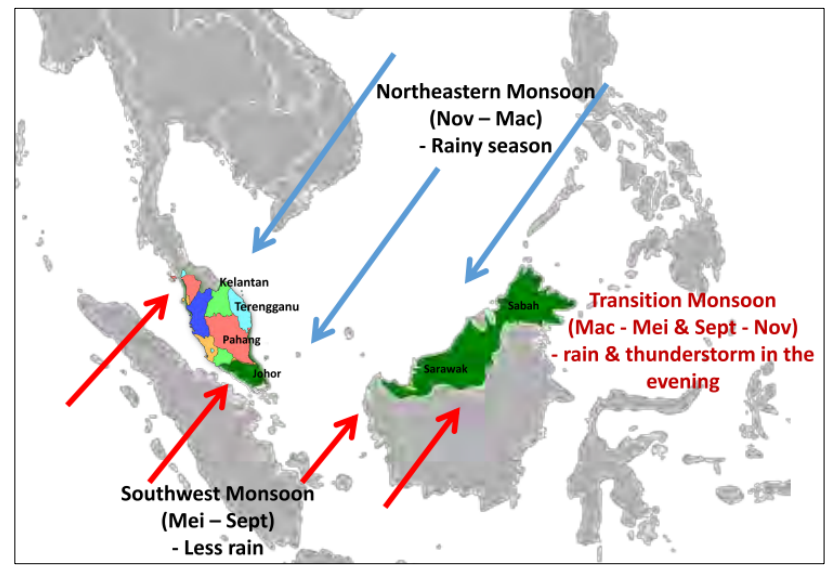

Figure 1. Malaysia Weather Pattern (National Flood Forecasting and Warning Centre, 2019).

Table 1 summarises the most significant flood events together with the estimated cost in Malaysian ringgits (MYR) or US dollars (\$).

\begin{tabular}{|c|c|c|c|c|}
\hline $\begin{array}{l}\text { Date } \\
\text { Year }\end{array}$ & $\begin{array}{l}\text { Cost } \\
\text { (millions) }\end{array}$ & Victims & Deaths & Reference \\
\hline 1926 & - & - & 45 & \multirow{3}{*}{$\begin{array}{l}\text { Noor } \\
\text { Syamini et } \\
\text { al., } 2014\end{array}$} \\
\hline 1967 & $>60 \mathrm{MYR}$ & $>250,000$ & - & \\
\hline 1971 & $>84.7$ MYR & 180,000 & 24 & \\
\hline 1996 & $\$ 300$ & $39,687^{*}$ & 241 & \multirow{2}{*}{ Chan, 2015} \\
\hline 2000 & - & 100,000 & 15 & \\
\hline 2001 & $\$ 0.65$ & $>10,000$ & $14 *$ & $\begin{array}{l}\text { Arturo et al., } \\
2017\end{array}$ \\
\hline 2003 & - & 31,046 & 5 & $D I D, 2009$ \\
\hline 2005 & 240 MYR & 99,405 & 14 & $\begin{array}{l}\text { Shah et al., } \\
2017\end{array}$ \\
\hline 2007 & $\$ 605$ & 137,533 & 17 & $\begin{array}{l}C F E-D M, \\
2019\end{array}$ \\
\hline 2007 & 316 MYR & 36,143 & 22 & $D I D, 2009$ \\
\hline 2008 & $\$ 21$ & $34,000 *$ & 28 & Chan, 2015 \\
\hline 2010 & $\$ 8$ & 50,000 & 4 & $\begin{array}{l}\text { Arturo et al., } \\
2017\end{array}$ \\
\hline 2013 & - & $34,000 *$ & 3 & $\begin{array}{l}\text { Buslima et } \\
\text { al., } 2018\end{array}$ \\
\hline 2014 & 2900 MYR & $>500,000$ & 25 & $\begin{array}{l}\text { Ghazali, } \\
2019 \\
\end{array}$ \\
\hline
\end{tabular}

* Water Related Disaster Resilience Approach: DID Way Forward' presentation by the Dato' Ir. Sabri bin Abdul Mulok; Deputy of Director General (Specialist Sector), DID.

Table 1. Major Flood Events in Malaysia.

Over a 20-year period from 1982 to 2003, the area of land in Malaysia considered flood-prone increased from $29,021 \mathrm{~km}^{2}$ to $29,799 \mathrm{~km}^{2}$ (JICA, 1982; KTA, 2003) as shown in the national 'Flood Prone Area' map: (https://www.water.gov.my/index.php/pages/view/419?m $\mathrm{id}=244)$. This is a trend that has continued, and by 2010 an estimated $33,298 \mathrm{~km}^{2}$ was considered to be flood-prone, representing $10.1 \%$ of the land area of Malaysia.

\subsection{Flood exposure}

Since the early settlement period, economic activities in Malaysia have been concentrated in the low-lying areas (Weng, 1996). Originally, these areas were valuable for agriculture and mining, and the river was used as 
transportation for people to commute. Over time, people migrated to the low-lying area and it rapidly became a centre for economic activity. Kuala Lumpur, for example, used to be a tin-mining area and is now one of the largest cities in Malaysia. Weng (1996) noted that in Malaysia the majority of migrants from rural to urban areas 'end up in low priority areas such as ex-mining land, hill slopes, and on squatter settlements below'. Thus migration to urban areas in Malaysia has tended to congregate in floodplains and other low-lying areas, making the population vulnerable to flooding, but also, by building in floodplains, potentially exacerbating the flood risk to others.

Amongst Association of Southeast Asian Nations (ASEAN) member states, Malaysia is considered to have the highest percentage of the population that is exposed to flooding (CFE-DM, 2019). The most recent study on flood exposure in Malaysia at the national scale was carried out by the Department of Irrigation and Drainage (DID, 2012b). The land-use categories in Malaysia most affected by floods are agriculture (41\% of flood-prone areas), forest $(35 \%)$ and open space (11\%). The flood-affected land used for residential, and commercial/industry was $739 \mathrm{~km}^{2}$ and $130 \mathrm{~km}^{2}$ respectively. In flood-prone agricultural areas, crops most affected were Oil Palm $\left(5,718 \mathrm{~km}^{2}\right)$ and Rubber $\left(2,903 \mathrm{~km}^{2}\right)$. The DID (2012) report also estimated that the total number of people in Malaysia affected by floods increased from 4.8 to 5.7 million people between 2003 and 2012. Floods were considered to have a greater impact on urban populations ( 3.8 million) than on those in more rural areas (1.9 million). However, the impact on rural populations has increased in recent years, rising from 1.4 million people at risk in 2002 to 1.9 million in 2012 .

\subsection{Flood vulnerability}

The majority of people who live in rural areas are economically lower and middle income families, and these groups often face the most severe effects of flooding (Hallegatte et al., 2015). A flood vulnerability assessment for Kuala Lumpur conducted by the Malaysian Department of Irrigation and Drainage (DID, 2003) found that social and physical vulnerability was higher than environmental and economic vulnerability (Nasiri et al., 2019). The survey also highlighted the high population density in Kuala Lumpur, with nearly 1.6 million residents in an area of $243 \mathrm{~km}^{2}$, a population density of $\sim 6500 / \mathrm{km}^{2}$. In the report (DID, 2003) several vulnerability indicators were considered to determine social, physical, economic and environmental vulnerability, but some of the indicators were found to be very context-specific, leading to problems with applying them to different regions. For example, the district flood vulnerability index (DFVI) could not easily be applied to other areas because locallysignificant variables such as rainfall amount and number of local rivers are not necessarily applicable to different geographic or climatic regions. However, using the normalised district flood vulnerability index, which ranges from 0 (low) to 1 (high), most of Kuala Lumpur scored above 0.5 (Nasiri et al., 2019).
The DID (2012b) study also indicated that the floodvulnerable area of Malaysia contains approximately 5.7 million people, or $21 \%$ of the population. The consequences of severe flooding can include long term impacts on health and education because of the economic cost of recovery from flooding (Azreen and Noy, 2011).

\subsection{The economic cost of floods in Malaysia}

Malaysia began to quantify economic losses from floods in the early 1980s. Three major reports contributed to the development of Malaysia's approach to estimating economic flood damages. The first, the 'National Water Resources Study', was completed in 1982 and provided the first systematic estimates of flood damage across Malaysia and laid the foundations for subsequent improvements to national flood damage assessments. The second, the 'Condition of Flooding in Malaysia' project (DID, 2003), developed an improved set of maps of flood inundation and land use for use in the estimation of losses, together with updated unit values and damage factors for various land use types. The third project, which was completed in 2012, revised the estimated cost of flood damages in Malaysia, taking account of recent changes in land use and more recent flood evidence (DID, 2012b). Flood risk maps and associated damage functions are now an established deliverable for major flood mitigation projects. Economic losses are routinely estimated and integrated with available data on probable extreme flows.

Between 2000 and 2010, economic losses from flooding for Malaysia, including Sabah and Sarawak, were estimated at MYR 1.15 billion or approximately $\$ 0.28$ billion (DID, 2012b). The expected annual damage (EAD) across the three Malaysian states most vulnerable to flooding (Kelantan, Johor and Kedah) was estimated to be MYR 8.3 million in total ( $\sim 2$ million). Following the 2014 floods, The Star newspaper (https://www.thestar.com.my/) reported that the total damage to the agriculture sector was approximately MYR 299 million ( $\sim 74$ million), with MYR 194 million of damage to agricultural produce, MYR 99.5 million of infrastructure damage, and MYR 5.5 million losses to agricultural assets. However, immediately following the 2014 flooding, the rebuilding of the agriculture sector was considered to have had a positive impact on economic growth (Shaari et al., 2017).

\section{Flood management in Malaysia}

\subsection{Governance and responsibility}

The devastating floods of 1971 (Table 1) resulted in flood warning and management becoming a national priority in Malaysia. The Ministry responsible for flood management in Malaysia identified several effective ways to combat flood hazard and consequences in Malaysia (Hussaini, 2007): (a) Flood prevention by avoiding new development in flood-prone areas, (b) Flood protection by implementing structural and non-structural approaches, (c) Flood preparedness through information dissemination to public, and (d) Flood recovery. Flood warning systems 
operating on major rivers were reviewed and national responsibility for 'flood management' was given to the Department of Irrigation and Drainage (DID). This led to the establishment of the Hydrological Division of DID which now acts as the national custodian for hydrological data (DID, 2009). Structural and engineering flood interventions were implemented in urban and rural areas, expanding the remit of DID from rural to both rural and urban areas (Ghazali, 2019).

Whilst DID plays a major role in managing floods through flood protection projects, other supporting agencies were set up to improve flood mitigation. In 1993, the National Hydraulic Research Institute of Malaysia (NAHRIM) was established. One of the aims of the new organisation was to conduct applied research within the water sector, including research into river basin processes, water resources, floods and climate change. More recently, in 2015 the Natural Disaster Relief Committee (NADMA) was formed to co-ordinate the management of national disasters (Noor Syamimi et al., 2014). Its role extends to improving flood preparedness and recovery by coordinating agencies in Malaysia whose remit impacts on flooding, for example land developers and property lawyers.

Following the 1971 floods, billions of ringgits were allocated by the Malaysian government to support flood mitigation projects, and this economic support has increased exponentially (ADRC, 2005). In the recent 2020 budget, MYR 443.9 million were allocated to flood mitigation projects with the aim of providing integrated planning and development of sustainable flood risk management. The economic support also aims to enhance flood risk management through the implementation of hazard and risk assessments to facilitate decision-making (MEPU, 2015).

\subsection{Flood warning, monitoring and mitigation}

A national guidelines policy for flood mitigation measures in Malaysia was introduced in 2000 and made mandatory. The policies relating to flood mitigation and warning emphasise the need for both structural (engineering) and non-structural flood prevention measures, alongside continued improvement of flood forecasting and warning systems (ADRC, 2005).

Structural flood mitigation measures require good quality estimates of storm return periods for guidance on the level of protection they should provide. These are provided in the DID Urban Stormwater Planning Manual (DID, 2012a), which provides mandatory national guidelines for project design and planning. Structural flood mitigation measures are required take account of socioeconomic and environmental impacts, and ideally include complementary nonstructural measures where applicable.

Examples of structural flood mitigation measures operational in Malaysia are provided in Table 2a, based on information provided by Zarina (2014). One example of effective flood mitigation in Malaysia in an area of rapid urban growth is the construction of the SMART Tunnel (Stormwater Management And Road Tunnel) in the Klang River Basin (Figure 2). Since its completion in late 2006, the SMART tunnel has reduced flood events in the Klang Valley with great success (Abdullah, 2004).

Where engineering solutions are not appropriate or available, alternative non-engineering measures are explored (Table 2b). In recent years there has been a greater emphasis on the use of Natural Flood Management schemes to provide an effective and sustainable approach to manage floods (Ghazali, 2019).

\begin{tabular}{|l|l|}
\hline (a) Structural Measures & Example \\
\hline $\begin{array}{l}\text { Upgrading the river and } \\
\text { drainage system }\end{array}$ & $\begin{array}{l}\text { Perai River and Muda } \\
\text { River }\end{array}$ \\
\hline $\begin{array}{l}\text { Construction of dams and } \\
\text { reservoirs }\end{array}$ & $\begin{array}{l}\text { Klang Gates Dam } \\
\text { Batu Dam }\end{array}$ \\
\hline Bypass & SMART Tunnel \\
\hline River diversions & $\begin{array}{l}\text { Keroh River, Gombak } \\
\text { River (Klang River } \\
\text { tributaries); Kedah } \\
\text { River }\end{array}$ \\
\hline $\begin{array}{l}\text { Embankment of river and the } \\
\text { beach }\end{array}$ & $\begin{array}{l}\text { Embankment at } \\
\text { Taman Sri Muda, } \\
\text { Shah Alam }\end{array}$ \\
\hline Pump house & Kg, Baru \\
\hline
\end{tabular}

\begin{tabular}{|l|l|}
\hline $\begin{array}{l}\text { (b) } \begin{array}{l}\text { Non-structural } \\
\text { Measures }\end{array} \\
\text { Floodplain management }\end{array}$ & Example \\
\hline $\begin{array}{l}\text { Flood forecasting and } \\
\text { warning }\end{array}$ & $\begin{array}{l}\text { Flood inundation map } \\
\text { Flood hazard map }\end{array}$ \\
\hline Flood mapping & map \\
\hline Land use planning & \\
\hline Education and awareness & \\
\hline Development control, MSMA & \\
\hline
\end{tabular}

Table 2. DID Flood Resilience Approaches for (a) structural, and (b) non-structural flood measures (based on Zarina, 2014).

Other non-structural approaches to flood adaptation such as relocation, public awareness campaigns and education are promoted and encouraged. For example, public awareness campaigns organised by DID include 'Love our River', 'One State One River' and 'River for Life'.

Regular monitoring of rainfall and river flows in Malaysia began in 1878 and 1910 respectively, and grew rapidly in response to the establishment of DID in 1932 to support water resources and agricultural management. Currently, daily flow observations are available for 154 gauging stations, and rainfall is monitored through a network of 1016 gauges. This is supplemented by a network of 42 principal weather stations and 380 auxiliary stations in addition to radar and satellite observations under the responsibility of the Department of Meteorology Malaysia (DMM). 


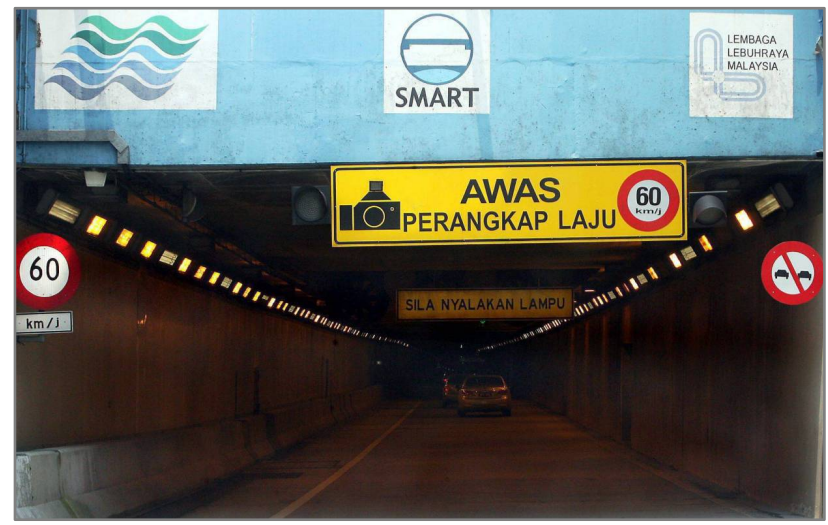

Figure 2. The Entrance of SMART Tunnel (The Star, 2019).

Continuous monitoring of water levels at stations across the country is essential for real-time management of flood risk and for longer term studies of trends and environmental change. Monitoring of flood extent and depth is undertaken by DID, and provides a valuable initial condition for pathway assessment of areal flood hazard (e.g. Abdullah et al., 2012), as well as real-time flood warning, such as the National Flood Forecasting and Warning System (NaFFWS) implemented in several major river basins as a collaborative initiative between DMM and DID (DMM, 2017).

\section{Towards a multi-scale approach to flood risk}

\subsection{Background: flood modelling in Malaysia}

Flood hazard assessments can be undertaken at a range of scales - global, continental, national, regional, catchment, and local scale of interest. The determination of the appropriate scale to use can be based on the size of the area, the required level of detailing, and the use and purpose of the modelling. The criteria for selection of the correct scale are subjective (de Moel et al., 2015). For example, local-scale modelling of inundation typically requires the use of a hydraulic model, but a stage-discharge function may suffice for a regional scale inundation model given the number of locations and catchments that will be covered, unless a sufficiently high performing computer is available. Large rivers and catchments that transverse national boundaries, e.g. River Niger in West Africa, more typically require the use of a regional-scale model, encompassing sub-catchment variability, to take account of international cooperation from member countries and different water management regimes in neighbouring countries. Several such rivers also abound in Europe.

In Peninsular Malaysia, there are no trans-national rivers except the Golok River, which serves as the border between Kelantan state and Thailand, and the largest catchment is the Pahang, which has an area of approximately $25,600 \mathrm{~km}^{2}$. With exception of a national scale study by the NAHRIM in 2010 (updated in 2014), most observation-based modelling of river flow variability and fluvial flooding is undertaken at a catchment scale (e.g. Tan et al., 2015, 2019; Wong et al., 2018; Cheah et al., 2019; Fu et al., 2020), with availability (or lack thereof) of long-term historical flow and water level records being a major factor in choice of modelling approach.

At the more local (river reach) scale, models are generally developed and calibrated for event-based flood analyses and/or hydraulic design application (e.g. Toriman et al., 2009). Catchment and reach-scale flood hazard models, which are typically calibrated to local observations, are able to provide flood simulations with a higher level of detail often lacking in regional-scale models, for which underpinning datasets of soils and anthropogenic influences are less readily available. Models such as the Soil and Water Assessment Tool (SWAT) and US Army Corp of Engineers HEC-HMS, which uses the Soil Conservation Survey Curve Number method to estimate effective rainfall, are commonly used, in addition to land surface models and Artificial Intelligence methods. For hydraulic modelling, common hydraulic models used by DID are HEC-RAS, MIKE 11 (developed by Danish Hydraulic Institute), and InfoWorks (developed by Wallingford Software) (DID, 2009).

A highly detailed (local-scale) flood assessment for a catchment is not only computationally demanding but more importantly data intensive, where relevant details must be obtained from ground observation, e.g. physical assessment of impervious surface, use of LIDAR-based DEM at high resolution, exact determination of water abstraction, areal determination of time to peak, and use of field surveyed soil information: land use, land cover, hydro-climatic, and hydraulic profile along the river network. If these data are readily available, a regionalscale flood model can be used for a small catchment, with a local-scale model more appropriate for smaller tributary catchments. Inevitably, the choice of a suitable scale, or use of different scale for hazard assessment, is applicationspecific. To date, no observed study has been completed in Malaysia using a multi-scale approach to flood modelling.

\subsection{A multi-scale approach to flood analysis}

Understanding flood risks, and the effectiveness of alternative management strategies that are credible at both a peninsular and the more local scale, relies upon a multiscale approach. This requires the development of an assessment framework that incorporates a common riskbased framing (hazards, exposure and vulnerability) and how these may change in time (due to climate, demographic or adaptation), to be developed in way that can be applied consistently at different scales. In this context, 'consistent' does not imply a uniform approach (using the same data and process models at all locations) but refers to the framework of the analysis, how climate change and adaptations are characterised, and how hazards, exposure and vulnerability are understood and characterised in the assessment of risk. The basic framework to be used in the FIAS project is shown in Figure 3. 


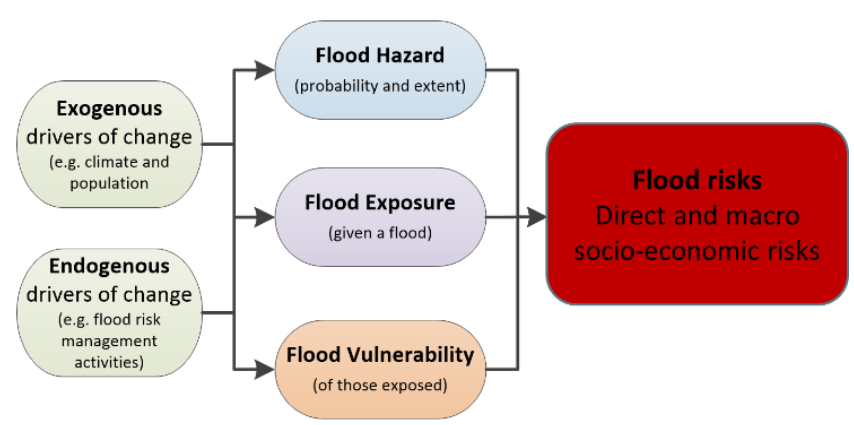

Figure 3. A common framework of flood analysis across scales (Sayers et al., 2015).

A key element of this approach is multi-scale modelling. This includes developing peninsular-scale modelling capability (using data and models capable of running at peninsular scales) and local-scale models within the same modelling framework but using more highly resolved input data or physical process representation where required. The process understanding gained at the local scale is being used to condition the representations in the peninsular-scale model, e.g. improving the representation of the relationship between a flood hazard and the economic impact. At a local scale, it is possible to represent the agricultural or building impacts taking account of the multiple influences (the season, the type of building, etc.). These are difficult to include in the peninsular-scale model, but it is possible to condition (not calibrate) the representation in the large-scale model. For example, modifying the JRC Global Depth Damage relationships (Huizinga et al., 2017) or estimating the standard of protection provided in areas where there are limited (to-no) direct data available on flood defence information.

The multi-scale approach also enables the peninsularscale model to influence local models. This is particularly the case in providing plausible boundary conditions in response to climate change, development or large-scale adaptation measures (such as dams or afforestation) that are beyond the boundaries of the local model but have an influence on local flood risks.

To be a true multi-scale assessment, and not simply an assessment of risk undertaken at different scales, this consistency of modelling framework is required, as well as an embedded ability to use added-value information established at one scale in the analysis at another scale.

\subsection{Multi-scale datasets for multi-scale modelling}

The development of environmental modelling frameworks is inevitably dependent on the existence and availability of underpinning datasets, and this is even more important for the development of models intended for applications at multiple scales. The rapid growth and availability of global environmental datasets provided by national and international organisations such as NASA, ESA, USGS, FAO, and by international climate modelling projects such as IPCC and CMIP, provide freely available and spatially consistent datasets to support hydrological and hazard modelling at global and regional scales.

For example, for the FIAS project, the regional-scale (peninsular) modelling will be applied at a $0.0083^{\circ} \times$ $0.0083^{\circ}$ grid resolution (equivalent to an approximate grid of $1.0 \times 1.0 \mathrm{~km}$ ) and will require spatial data for elevation, flow directions, soils information, water bodies (lakes and reservoirs) and land use. These data can be obtained from multiple global sources including elevation and flow directions from the HydroSHEDS database (Lehner et al., 2008), soil hydraulic parameters from ISRIC - World Soil Information (Ribeiro, 2018), delineation of water bodies from the HydroLAKES database (Messager et al., 2016) and land cover from ESA CCI Land Cover (ESA, 2017).

Although freely available and generally of good quality, some of these global datasets (e.g. soils) have been assembled from a 'jigsaw' of local datasets available from individual countries. While many countries (e.g. USA, UK) require government-funded research projects to make their datasets available to other researchers to support long-term science development, not all do, resulting in a patchwork of data quality. In a recent study of uncertainties in crop models, Folberth et al. (2016) identified soil data as one of the primary causes of global crop model uncertainty.

Local country data (e.g. for soils, elevation and land cover) are often of higher quality than global datasets and more tailored to local conditions, but are sometimes less readily available than global datasets, and may require payment of licence fees for research use. Thus in order to develop flood risk modelling approaches at multiple scales, there is a parallel requirement to develop spatial datasets that are consistent across multiple scales.

The trade-off between high quality local data and readily available global data is less acute with the weather and climate data needed to drive flood models. Although for modelling small catchments, where local rainfall and potential evaporation observations from a weather station located in the catchment are highly desirable, for national or large catchment applications, the loss in model performance from using regional or global weather datasets can be modest.

For the FIAS project, weather and climate data to drive the flood models consists of daily or sub-daily rainfall data and near-surface air temperature data for the estimation of potential evaporation $(\mathrm{PE})$. The $0.05^{\circ} \times 0.05^{\circ}$ gridded hydro-meteorological dataset for Peninsular Malaysia from Wong et al. (2011) will be used, and supplemented by global datasets as required. For analyses of the impact of projected climate change on flood risk, the observed rainfall and PE used by the flood risk models will be replaced by an ensemble of regional climate model simulations for South-East Asia (Ngo-Duc et al., 2017). These weather and climate driving datasets are freely available to download and use with appropriate acknowledgements and will be used by models at both local and national scales.

\subsection{Role of case studies}

The FIAS project will use local case studies in Malaysia to help test, compare and improve understanding of flood drivers and impacts at multiple scales. Targeted surveys and interviews in selected case studies in Kelantan and the Klang Valley (shown in Figure 4), complemented 
by data from local authorities, newspaper reports and NGO sources, will provide information on the socio-economic impact profiles of previous flood events of different magnitudes and durations. Tangible impacts will be estimated and intangible impacts qualitatively assessed. This information will be used to define a typology of linkages between floods, impacts and damages, and thereby identify critical flood depth thresholds leading to impacts. It will also provide new knowledge of community response to floods events and factors that influence mitigation behaviour and contribute to the evidence base for social learning. Upscaling from case-study scale to national scale will take place through innovative coupling of local information about flood exposure and vulnerability, and associated damages, with national-scale geophysical and socio-economic datasets.

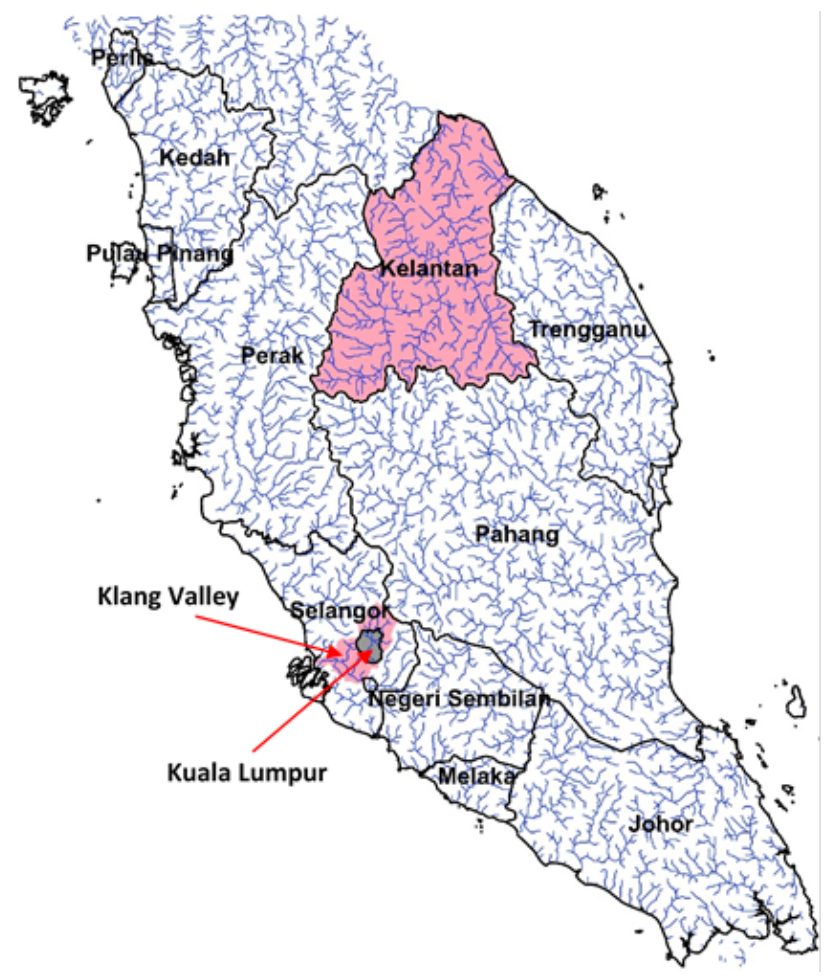

Figure 4. Map of Peninsula Malaysia showing federal states (delineated by black lines) and a $1 \mathrm{~km}$ resolution river network (blue line). FIAS case study areas are highlighted in pink, and the city of Kuala Lumpur is shaded in grey.

\section{The challenges ahead}

\subsection{Developing a multi-scale model}

The challenge posed in translating site-specific information to generalised models has been considered elsewhere in hydrology and environmental science, including groundwater modelling, climate modelling, precipitation infilling and water resource studies (Blöschl et al., 1995). Such 'upscaling' approaches are used to condition larger scale models using point data. Upscaling broadly take one of two approaches (Beven et al., 1996). The first of these uses a conceptual understanding of an environmental system to develop a model structure which is then calibrated. The second uses both the physical structure identified from local scale observations and the associated inferred parameter values. Recent efforts have been made to integrate such conceptual and physical models to construct models which are both physically plausible and flexible (Fraser et al., 2013). Such 'multiscale' models (e.g. Samaniego et al., 2010) have been identified as a research priority for the improvement of large-scale hydrological models (Bierkens, 2015).

Identification of techniques to integrate information on flood hazard, vulnerability and damages at local and national scales is one of the key challenges of the FIAS project. For example, detailed information from case study surveys and interviews on impacts of flooding on agricultural or particular types of domestic properties may need to be generalised for inclusion in the peninsular-scale model, but could be used to support case study analyses of flood damages. The availability of suitably scaled and typologically linked spatial datasets for land cover and anthropogenic changes to the hydrological regime, at both local and national scales, will also be key to developing new methods for representing flood risk at multiple scales.

\subsection{Future scenarios of flood risk}

The FIAS project aims to provide the first multi-scale approach to assessing the impact of projected climate change on flood risk across Malaysia. To date, such studies have typically only been completed in more developed economies, such as the study by Sayers et al. (2015) on future flood risk assessment in the UK, using relevant inputs of population growth, climate change, and different adaptation measures. Across Malaysia there has instead been a greater emphasis on managing post-disaster situations, such as the physical needs and health of the population. Baharuddin et al. (2015) showed that over 200 victims were being admitted to hospital emergency units every day during the 2014 flood. One factor influencing the high impact of flooding on local populations may be the low uptake of flood insurance policies in Malaysia, as awareness of such products is still low (Aliagha et al., 2014).

Globally, environmental changes indicative of a warming climate have already been observed. These include: global land and ocean temperature rises of $0.8^{\circ} \mathrm{C}$ above pre-industrial levels of the 18th century; sea level rise of $0.8 \mathrm{~mm} /$ year from 1971 to 2010 ; and global glaciers have been retracting at a likely rate of $226 \mathrm{Gt} /$ year from 1971 to 2009 and $301 \mathrm{Gt} /$ year between 2005 and 2009 (IPCC, 2013; World Bank, 2013). There is no reason to believe Malaysia will avoid the impact of these long-term shifts in the climate. A catchment based study on the impact of climate change on drought in the Johor river basin using downscaled products from the archives of CORDEX SEA and Representative Concentration Pathways (RCPs) of 4.5 and 8.5 (Tan et al., 2019) showed significant increase in hydro-meteorological droughts (in the range of $24 \%$ ) for most ensemble members. Another climate change impact study undertaken by NAHRIM (2004) for Peninsular Malaysia found considerable spatial 
variation in the impact of climate change on river flows for different catchments across the region.

A 2016 publication by the Malaysian Department of Statistics (https://www.dosm.gov.my/v1/) indicated that by 2040 , the population is expected to increase by $45 \%$ from 28.6 million in 2010 to 41.5 million in 2040, despite a decrease in the population growth rate from 1.8 to $0.8 \%$. Over the same period, the proportion of the population aged over 65 years is expected to increase from 5\% to $14.5 \%$, potentially tripling the size of the population who may be vulnerable to natural hazards such as flooding. With floods in Malaysia considered to have a greater impact on urban populations than those in more rural areas, careful choice in planning the locations of new housing developments will be vital to safeguarding future society.

\section{Concluding remarks}

The Flood Impact Across Scales (FIAS) project is a collaboration between Malaysian and UK researchers addressing flood hazard impacts, hydrology, hydroclimatology, flood inundation, economics and adaptation within a coherent multi-scale framework. This interdisciplinary research group was been formed through connections developed at networking events hosted by the Natural Environment Research Council (NERC) and the British Council in 2017 and scholarships to the UK funded by the Malaysian Government.

The multi-scale approach to flood risk developed by the FIAS consortium for both present-day and projected future scenarios aims to provide new data, science and understanding to support the development of robust future flood adaptation scenarios and planning in Malaysia. The FIAS project started in 2019 and will run for three years. The project team will provide research outputs relevant for flood stakeholders at both local and peninsular scales, and will increase understanding of flood risk through training $\mathrm{PhD}$ students and early career researchers in both Malaysia and the UK. Datasets, publications and products derived from this research will also be made available to stakeholders and other researchers to support long-term science development.

\section{Acknowledgement}

The FIAS project is funded under the Newton-Ungku Omar Fund 'Understanding of the Impacts of Hydrometeorological Hazards in South East Asia' call. The grant is jointly awarded by the Natural Environment Research Council (NERC) and the Ministry of Higher Education Malaysia.

\section{References}

1. Abdullah, A.F., Z. Vojinovic, R.K. Price, N.A.A. Aziz (2012). Improved methodology for processing raw LiDAR data to support urban flood modellingaccounting for elevated roads and bridges. Journal of Hydroinformatics 14(2): 253-269.
2. Abdullah, K. (2004). Stormwater Management and Road Tunnel (SMART) a Lateral Approach to Flood Mitigation Works. International Conference on Bridge Engineering and Hydraulic Structures. Selangor, Malaysia. 26-28 July 2004.

3. Aliagha, U.G., T.E. Jin, W.W. Choong, M. Nadzri Jaafar and H.M. Ali (2014) Factors Affecting Flood Insurance Purchase in Residential Properties in Johor, Malaysia. Nat. Hazards Earth Syst. Sci. 14, 32973310.

4. Arturo, M., R. Estrada, E. Koutronas, M. Tahir and N. Mansor. (2017). Hydrological hazard assessment: THE 2014-15 Malaysia floods. International Journal of Disaster Risk Reduction 24, 264-270.

5. Asian Disaster Reduction Center (ADRC) (2005). Total Disaster Management - Good Practices 2005 Chapter 3.3.6: 80-81. Retrieved from https://www.adrc.asia/publications/TDRM2005/TDR $\mathrm{M}$ Good Practices/PDF/PDF2005e/Chapter3 3.3.6.pdf

6. Azreen, K., and I. Noy (2011). Poverty and Natural Disasters: A Meta-Regression Analysis. Review of Economics and Institutions 7(2).

7. Baharuddin, K.A., S.F.A. Wahab, N.H.N A. Rahman, N.A.N. Mohamad, T.H.T. Kamauzaman, A. Yazid Md Noh and M.R.A. Majid (2015). The record-setting flood of 2014 in Kelantan: Challenges and recommendations from an emergency medicine perspective and why the medical campus stood dry. Malaysian Journal of Medical Sciences 22(2), 1-7.

8. Beven, K., and J. Fisher. (1996). Remote Sensing and Scaling in Hydrology. Scaling up in Hydrology using Remote Sensing. Wiley, London.

9. Bierkens, M. F. P. (2015). Global hydrology 2015: State, trends, and directions. Water Resources Research 51(7): 4923-4947.

10. Blöschl, G. and M. Sivapalan (1995). Scale issues in hydrological modelling: a review. Hydrological Processes 9(3-4): 251-290.

11. Buslima, F.S., R.C. Omar, T.A. Jamaluddin and H. Taha (2018). Flood and flash flood geo-hazards in Malaysia. International Journal of Engineering and Technology (UAE) 7(4), 760-764.

12. Center for Excellence in Disaster Management and Humanitarian Assistance (CFE-DM) (2019). MALAYSIA: Disaster Management Reference Handbook, June 2019. Retrieved from https://www.cfe-dmha.org/DMHAResources/Disaster-Management-ReferenceHandbooks

13. Chan, N.W. (2015). Impacts of Disasters and Disaster Risk Management in Malaysia: The Case of Floods. In Resilience and Recovery in Asian Disasters (December, pp. 239-265). Springer, Japan.

14. Cheah, R., L. Billa, A. Chan, F.Y. Teo, B. Pradhan, and A.M. Alamri (2019). Geospatial Modelling of Watershed Peak Flood Discharge in Selangor, Malaysia. Water, 11(12), 2490.

15. Crichton, D. (1999). The Risk Triangle. In: Ingleton, J., Ed., Natural Disaster Management, Tudor Rose, London, 102-103. 
16. de Moel, H., B. Jongman, H. Kreibich, B. Merz, E. Penning-Rowsell, and P. J. Ward (2015). Flood risk assessments at different spatial scales. Mitigation and Adaptation Strategies for Global Change. 20, 865890. doi:10.1007/s11027-015-9654-z

17. Department of Meteorology, Malaysia (DMM) (2017). Annual Report 2017. pp. 90. Available at: http://www.met.gov.my/content/pdf/penerbitan/lapor antahunan/laporantahunan2017.pdf

18. Department of Irrigation and Drainage, Malaysia (DID) (2003). Main Report: Updating of Condition of Flooding in Malaysia. Submitted by KTA as part of Final Report. Vol. 2.

19. Department of Irrigation and Drainage, Malaysia (DID) (2009). DID Manual (Volume 1 - Manual on Flood Management). 1, 523.

20. Department of Irrigation and Drainage, Malaysia (DID) (2012a). Urban Stormwater Management for Malaysia (MSMA). Government of Malaysia Publication. 2nd Edition.

21. Department of Irrigation and Drainage, Malaysia (DID) (2012b). Main Report: Updating of condition offlooding and flood damage assessment in Malaysia. Submitted by Dr. Nik \& Associates as part of Final Report. Vol. 2.

22. ESA (2017). Land Cover CCI Product User Guide Version 2. Tech. Rep. Available at: maps.elie.ucl.ac.be/CCI/viewer/download/ESACCILC-Ph2-PUGv2 2.0.pdf

23. Folberth, C., R. Skalsky, E. Moltchanova, J. Balkovic, L.B. Azevedo, M. Obsersteiner, and M, van der Velde (2016) Uncertainty in soil data can outweigh climate impact signals in global crop yield simulations. Nature Communications 7:11872.

24. Fraser, C.E., N. McIntyre, B.M. Jackson and H.S. Wheater (2013). Upscaling hydrological processes and land management change impacts using a metamodeling procedure. Water Resources Research 49(9): 5817-5833.

25. Fu, M., T. Fan, Z.A. Ding, S.Q. Salih, N. Al-Ansari and Z.M. Yaseen (2020). Deep Learning DataIntelligence Model Based on Adjusted Forecasting Window Scale: Application in Daily Streamflow Simulation. IEEE Access, 8, 32632-32651.

26. Ghazali, N.H.M. (2019). Flood adaptation \& mitigation in Malaysia. Sharing best practices on water management, 2nd Malaysia-Netherlands Water Dialogue, 2 October 2019. Kuala Lumpur.

27. Hallegatte, S., M. Bangalore, L. Bonzanigo, M. Fay, T. Kane, U. Narloch, J. Rozenberg, D. Treguer and A. Vogt-Schilb (2015). Poverty and climate change: Natural disasters, agricultural impacts and health shocks. Towards a Workable and Effective Climate Regime, Chapter 26. Centre for Economic Policy Research, London.

28. Huizinga J., H. de Moel, W. Szewczyk (2017). Global flood depth-damage functions: Methodologies and the database with guidelines. JRC Technical Reports. doi:10.2760/16510. Publications Office of the European Union.

29. Hussaini, A. (2007) 'Flood and drought management in Malaysia', Speech Given on 21 June 2007, Ministry of Natural Resources and Environment, Malaysia, Kuala Lumpur.

30. IPCC (2013). Climate Change 2013: The Physical Science Basis. Contribution of Working Group I to the Fifth Assessment Report of the Intergovernmental Panel on Climate Change. Cambridge University Press, UK.

31. Japan International Corporation Agency (JICA) (1982). National Water Resources Study.

32. KTA (2003). National Register of River Basin Final Report Volume 2: Updating Condition of Flooding in Malaysia. Main Report. Submitted by KTA Tenega Sdn Bhd to the Department of Drainage and Irrigation, Malaysia.

33. Lehner, B., K. Verdin and A. Jarvis (2008). New global hydrography derived from spaceborne elevation data. Eos, Transactions, $A G U$ 89(10): $93-$ 84.

34. Malaysia Economic Planning Unit (MEPU) (2015). Eleventh Malaysia Plan, Chapter 6. Retrieved from: https://www.pmo.gov.my/dokumenattached/RMK/R MKe-11Book.pdf

35. Messager, M. L., B. Lehner, G. Grill, I. Nedeva, O. Schmitt (2016). Estimating the volume and age of water stored in global lakes using a statistical approach. Nature Communications 7, 13603.

36. Mohamed, S., I. Y. Ebenehi, A. Adaji, T. W. Seow, N. W. Chan, K. C. Goh and M. H. I. Abd. Rahim. (2017). Impacts of flood on children and adults' health and ways to sustainable development. IOP Conference Series: Materials Science and Engineering 271(1) 012025.

37. Munich Re (2017). Natural Catastrophes 2016: Analyses, assessments, positions. Topics Geo. A. Able, Munich.

38. Nasiri, H., M.J.M. Yusof, T.A.M. Ali and M.K.B. Hussein (2019). District flood vulnerability index: urban decision-making tool. International Journal of Environmental Science and Technology 16, 22492258.

39. National Flood Forecasting and Warning Centre (PRABN) (2019). Flood Risk Management Case Visit Asean Level In Malaysia. Asean Committee on Disaster Management (ACDM) Meeting.

40. National Hydraulic Research Institute of Malaysia (NAHRIM) (2014). Extension Study of the Impact of Climate Change on the Hydrologic Regime and Water Resources of Peninsular Malaysia. The Ministry of Natural Resources and Environment, Malaysia.

41. Ngo-Duc, T., F.T. Tangang, J. Santisirisomboon, F. Cruz, L. Trinh-Tuan, T. Nguyen-Xuan, T. Phan-Van, L. Juneng, G. Narisma, P. Singhruck, D. Gunawan and E. Aldrian (2017). Performance evaluation of RegCM4 in simulating extreme rainfall and temperature indices over the CORDEX-Southeast, Asia region. Int. J. Climatol. 37: 1634-1647.

42. Noor Syamimi, I., M.D. Azharudin and A.R. Mohamad Rodzi (2014). Sejarah Banjir Besar di Semenanjung Malaysia, 1926-1971. Jurnal Perspektif 3(6), 54-67.

43. Reuters (2015). Malaysia Floods to Have Limited Credit Impact on Insurers. Fitch. Singapore. 
44. Ribeiro, E. and N. Batjes (2018). WOSIS Procedure Manual 2018. ISRIC Report 2018/01. doi: 10.17027/isric-wdesoils.20180001

45. Samaniego, L., R. Kumar and S. Attinger (2010). Multiscale parameter regionalization of a grid-based hydrologic model at the mesoscale. Water Resources Research 46(5).

46. Sayers, P.B., M.S. Horritt, E. Penning-Rowsell and A. Mckenzie. (2015). Climate Change Risk Assessment 2017: Projections of future flood risk in the UK, pp. 125. Sayers and Partners LLP report for the Committee on Climate Change.

47. Shaari, M., M. Karim and B. Basri (2016). Flood Disaster and GDP Growth in Malaysia. ). European Journal of Business and Social Sciences 4 (10): 27 40 .

48. Shaari, M.S., M.Z. Abd Karim and B. Hasan-Basri (2017). Does Flood Disaster Lessen GDP Growth? Evidence from Malaysia's Manufacturing and Agricultural Sectors. Malaysian Journal of Economic Studies, 54(1): 61-81.

49. Shah, S.M.H., Z. Mustaffa and K.W. Yusof (2017). Disasters Worldwide and Floods in the Malaysian Region: A Brief Review. Indian Journal of Science and Technology 10(2).

50. Tan, M.L., A.L. Ibrahim, Z. Yusop, Z. Duan and L. Ling (2015). Impacts of land-use and climate variability on hydrological components in the Johor River basin, Malaysia. Hydrological Sciences Journal, 60(5), 873-889.

51. Tan, M. L., L. Juneng, F. T. Tangang, N. W. Chan and S. T. Ngai (2019). Future Hydro-Meteorological Drought of the Johor River Basin, Malaysia, based on CORDEX-SEA projections. Hydrological Sciences Journal 64:8, 921-933.

52. The Star (2019, Dec 24). 'Operators Working on Reopening SMART Tunnel After Monday Downpour'.

https://www.thestar.com.my/news/nation/2019/12/24 /operators-working-on-reopening-smart-tunnel-aftermonday-downpour

53. Toriman M.E., A.J. Hassan, M.B. Gazim, M. Mokhtar, S.A. Sharifah Mastura, O. Jaafar, O. Karim and N.A. Abdul-Aziz (2009) Integration of 1-d hydrodynamic model and GIS approach in flood management study in Malaysia. Res J Earth Sci, 1(1), $22-27$.

54. UNISDR (2017). Words into Action guidelines: Hazard Specific Risk Assessment. 4. Flood Hazard and Risk Assessment, pp.46. Available at: https://www.unisdr.org/files/52828 04floodhazardan driskassessment.pdf

55. USDA (2015). Malaysia 2014/15 Palm Oil Production Affected by Flooring. Commodity Intelligence Reports. Office of Global Analysis, Washington D.C.

56. World Bank (2013). Turn down the heat: climate extremes, regional impacts and the case for resilience. A Report for the World Bank by the Potsdam Institute for Climate Impact Research and Climate Analytics.

57. Weng C. N. (1996). Risk, Exposure and Vulnerability to Flood Hazards in a Rapidly Developing Country:
The Case of Peninsular Malaysia. Akadernika 49 (Julai): $107-137$.

58. Wong, C-L., R. Venneker, A.B.M. Jamil and S. Uhlenbrook (2011). Development of a gridded daily hydrometeorological data set for Peninsular Malaysia. Hydrological Processes 25(7): 1009-1020.

59. Wong, C., Z. Yusop, R. Venneker and S. Uhlenbrook (2018). Effects of Topographic Heterogeneity on Coarse Resolution Grid-Based Runoff Simulation Assessment for Three River Basins in Peninsular Malaysia. Environ. Model Assess. 23, 277-288.

60. Zarina, B. (2014). Flood Hazard Maps: An Update. Words into Action Guidelines: National Disaster Risk Assessment Hazard Specific Risk Assessment 12(29), 626-634. 